\title{
Thyroid Dysfunction in Patient with Abnormal Uterine Bleeding in a Tertiary Hospital of Eastern Nepal: A Descriptive Cross-sectional Study
}

\author{
Bishal Raj Joshi, ${ }^{1}$ Shikha Rizal,' Shanti Subedi² \\ 'Department of Biochemistry, Nobel Medical College, Biratnagar, Nepal, ${ }^{2}$ Department of Obstetrics and \\ Gynaecology, Nobel Medical College, Biratnagar, Nepal.
}

\section{ABSTRACT}

Introduction: Thyroid hormone is known to affect reproductive biology. Abnormal uterine bleeding is one of the common presentations in gynaecology outpatient departments and thyroid dysfunction is known to affect its progression. This study aims to find the prevalence of thyroid dysfunction in diagnosed cases of abnormal uterine bleeding in patients in a tertiary hospital of eastern Nepal.

Methods: A descriptive cross-sectional study was conducted in patients diagnosed with abnormal uterine bleeding in a tertiary care hospital of eastern Nepal from April 2019-March 2020 after taking ethical clearance from the Institutional Review Committee. On basis of inclusion and exclusion criteria, 95 cases of abnormal uterine bleeding were included in the study. A blood sample was taken and a thyroid function test was done by chemiluminescence assay on an automated analyzer. Convenient sampling method was used for sample collection. Statistical analysis was done using Statistical Package for the Social Sciences version 16. Point estimate at 95\% Confidence Interval was calculated along with frequency and proportion for binary data.

Results: Out of the total cases of abnormal uterine bleeding, 15 (15.79\%) (8.46-23.12 at 95\% Confidence Interval) had thyroid dysfunction. Among total cases, $80(84.21 \%)$ were euthyroid. The mean age of the patients was $33 \pm 8$ years. Among thyroid dysfunction, 9 (60.0\%) were hypothyroid, $4(26.66 \%)$ were subclinical hypothyroid, and $2(13.33 \%)$ were hyperthyroid.

Conclusions: Thyroid dysfunction was common among patients with abnormal uterine bleeding, with hypothyroidism being the most common type.

Keywords: hypothyroidism; menorrhagia; thyroid function tests.

\section{INTRODUCTION}

The impact of thyroid hormone on reproductive biology has been studied. ${ }^{1}$ Due to similarity of Thyroid Stimulating Hormone (TSH) to gonadotropins - Follicle Stimulating Hormone (FSH) and, Leutinizing Hormone (LH) and, presence of thyroid hormone receptors on ovaries, thyroid hormones can affect menstrual cycle by direct impact on ovaries or through impact on sex hormone binding globulin (SHBG), prolactin and gonadotropin releasing hormone $(\mathrm{GnRH}) .^{1,2}$ Abnormal uterine bleeding (AUB) is known to affect $10-15 \%$ women of reproductive age globally, with prevalence of $6.2 \%$ in Nepal. ${ }^{3,4}$

Hypothyroidism has been found to cause menorrhagia and hyperthyroidism to cause oligomenorrhoea and amenorrhoea. ${ }^{1}$ Most cases of anovulatory bleeding can be treated by hormonal and non-hormonal medicines, thus avoiding surgeries. ${ }^{5}$ Treating thyroid function has shown to improve the menstrual abnormalities..$^{6,7}$

This study aims to find the prevalence of thyroid dysfunction in women of reproductive age with abnormal uterine bleeding in a tertiary hospital of eastern Nepal.

\section{METHODS}

This is a descriptive cross-sectional study that was carried out in department of Biochemistry in collaboration with department of gynaecology at Nobel Medical College, Biratnagar for 12 months from April 2019 to

Correspondence: Dr. Bishal Raj Joshi, Department of Biochemistry, Nobel Medical College and Teaching Hospital, Biratnagar, Nepal. Email: drbishaljoshi@gmail.com, Phone: $+977-9852027758$. 
March 2020. Total of 95 diagnosed cases of Abnormal uterine bleeding in gynaecology outpatient department (OPD) were enrolled in the study. Ethical clearance was obtained from Institutional review committee of Nobel Medical College and Teaching Hospital, Biratnagar. Informed consent was taken from patients. Inclusion criteria for selection of patients was diagnosed case of AUB. Exclusion criteria were patients on thyroid medication, under hormonal treatment, contraceptive devices, pregnant patients, bleeding disorders, abortion history within three months, patient with known liver disease and known cases of cancer of genital organs.

Convenient sampling method was used for sample collection. Sample size was calculated by following formula:

$$
\begin{aligned}
\mathrm{n} & =\mathrm{Z}^{2} \times \mathrm{p} \times(1-\mathrm{p}) / \mathrm{e}^{2} \\
& =(1.96)^{2} \times 0.2 \times(1-0.2) /(0.09)^{2} \\
& =76
\end{aligned}
$$

Where,

$\mathrm{n}=$ minimum sample size required

$Z=1.96$ at $95 \%$ Confidence Interval (Cl)

$p=$ prevalence of thyroid dysfunction in AUB, $20 \%{ }^{4}$

$q=1-p$

$\mathrm{e}=$ margin of error, $9 \%$

The sample size was calculated was 76 . Adding a $10 \%$ non-response rate, the sample size was calculated as 83. We have collected data from 95 participants.

A complete history of age, parity, menstrual history, onset and duration of menstrual problems, volume of blood flow and any other relevant complaints was taken. After case history and clinical examination, urine pregnancy test followed by bleeding time, clotting time, ultrasonography of abdomen and pelvis was done. After all the exclusion criteria ruled out and diagnosis confirmed, patient was prepared for Thyroid function test (TFT).

Approximately $3 \mathrm{ml}$ venous blood sample was collected in a yellow capped plain vial, from antecubital vein under strict aseptic conditions following the universal precautions. Centrifugation was done at 3000rpm for 10 minutes and separated serum was stored at $-20^{\circ} \mathrm{C}$ until analysis. Serum triiodothyronine (T3), Thyroxine (T4) and thyroid stimulating hormone (TSH) level were measured by chemiluminescence assay on Advia centaur XP immunoassay analyzer. Normal range for T3, T4 and TSH was respectively $2.5-4.16 \mathrm{pg} / \mathrm{ml}, 0.89$ $1.76 \mathrm{ng} / \mathrm{dl}$ and $0.34-5.12 \mathrm{lU} / \mathrm{ml}$ and thyroid function was interpreted as:

\begin{tabular}{|ll|}
\hline Table 1. Values. & \\
\hline Findings & Interpretation \\
All T3, T4 and TSH within normal & Euthyroid \\
range & \\
T3 $<2.5 \mathrm{pg} / \mathrm{ml}, \mathrm{T} 4<0.89 \mathrm{ng} / \mathrm{dl}$ and & Hypothyroid \\
$\mathrm{TSH}>5.12 \mathrm{IU} / \mathrm{ml}$ & \\
$\mathrm{T} 3$ and $\mathrm{T} 4 \mathrm{within}$ normal range and & Subclinical \\
$\mathrm{TSH}>5.12 \mathrm{IU} / \mathrm{ml}$ & hypothyroid \\
$\mathrm{T} 3>4.16 \mathrm{pg} / \mathrm{ml}, \mathrm{T} 4>1.76 \mathrm{ng} / \mathrm{dl}$ and & Hyperthyroid \\
$\mathrm{TSH}<0.34 \mathrm{IU} / \mathrm{ml}$ & \\
$\mathrm{T} 3$ and $\mathrm{T} 4 \mathrm{within}$ normal range and & Subclinical \\
$\mathrm{TSH}<0.34 \mathrm{IU} / \mathrm{ml}$ & hyperthyroid \\
\hline
\end{tabular}

The data was collected and entered in MS-excel 2013 and analyzed using the Statistical Package for Social Sciences (SPSS) version 16 software. Point estimate at $95 \%$ Confidence Interval and descriptive statistics were calculated.

\section{RESULTS}

Out of the total cases of abnormal uterine bleeding, $15(15.79 \%)(8.46-23.12$ at $95 \% \mathrm{Cl}$ ) had thyroid dysfunction. The mean age for patients suffering from abnormal uterine bleeding was found to be $33 \pm 8$ years and patients from the age group 24-34 years were more common $36(37.9 \%)$ followed by age group $35-44$ years $31(32.6 \%)$ (Table 2$)$.

\begin{tabular}{|lc|}
\hline Table 2. Age-wise distribution of occurrence of AUB. \\
\hline Age group (years) & $\mathbf{n}(\%)$ \\
$15-24$ & $18(18.9)$ \\
$25-34$ & $36(37.9)$ \\
$35-44$ & $31(32.6)$ \\
$\geq 45$ & $10(10.5)$ \\
\hline
\end{tabular}

About 80 (84.21\%) were euthyroid (Table 3).

\begin{tabular}{|lc|}
\hline Table 3. Thyroid status of study population. \\
\hline Thyroid status & $\mathbf{n}(\%)$ \\
Thyroid dysfunction present & $15(15.79)$ \\
Euthyroid & $80(84.21)$ \\
\hline
\end{tabular}

Hypothyroidism was most common among thyroid dysfunction 9 (60\%), followed by subclinical hypothyroidism $4(26.66 \%)$ and hyperthyroidism 2 (13.33\%) (Figure 1).

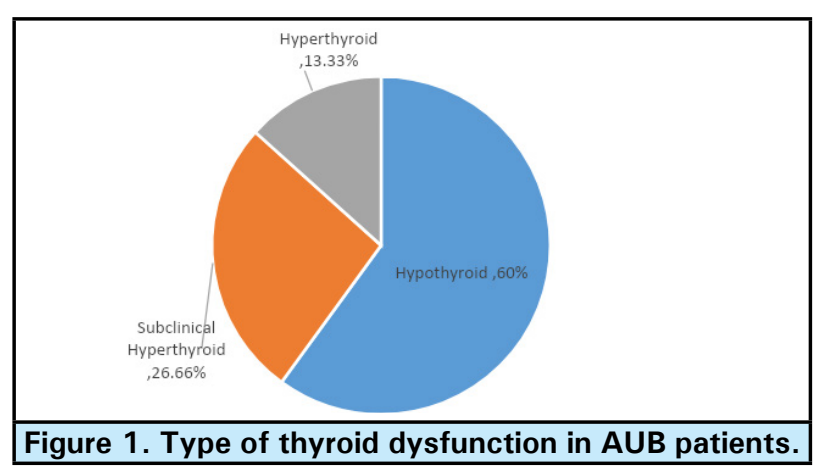


Joshi et al. Thyroid Dysfunction in Patient with Abnormal Uterine Bleeding in a Tertiary Hospital of Eastern Nepal...

Among the uterine bleeding, menorrhagia was most common $45(47.37 \%)$ followed by metrorrhagia 20 $(21.05 \%)$, oligomenorrhoea was the least common $3(3.16 \%)$. Thyroid dysfunction commonly occurred in menorrhagia followed by other forms. Among menorrhagia cases, 36 (80\%) were euthyroid, 7 $(15.5 \%)$ were hypothyroid and 2 (4.5\%) were subclinical hypothyroid (Table 3).

\begin{tabular}{|llllll|}
\hline \multicolumn{7}{|l}{ Table 3. Thyroid status in different } & forms of Abnormal Uterine Bleeding. & & \\
\hline & $\begin{array}{l}\text { Euthyroid } \\
\mathbf{n}(\%)\end{array}$ & $\begin{array}{l}\text { Hypo thyroid } \\
\mathbf{n}(\%)\end{array}$ & $\begin{array}{l}\text { Subclinical Hypo } \\
\text { thyroid } \mathbf{n}(\%)\end{array}$ & $\begin{array}{l}\text { Hyper thyroid } \\
\mathbf{n}(\%)\end{array}$ & Total $\mathbf{n}(\%)$ \\
Menorrhagia & $36(80)$ & $7(15.5)$ & $2(4.5)$ & 0 & $45(100)$ \\
Metrorrhagia & $18(90)$ & $2(10)$ & 0 & 0 & $20(100)$ \\
Polymenorrhoea & $11(84.6)$ & 0 & $2(15.4)$ & 0 & $13(100)$ \\
Hypomenorrhoea & $5(83.34)$ & 0 & 0 & $1(16.66)$ & $6(100)$ \\
Oligomenorrhoea & $2(66.66)$ & 0 & 0 & $1(33.34)$ & $3(100)$ \\
Menometrorrhagia & $8(100)$ & 0 & 0 & 0 & $8(100)$ \\
\hline
\end{tabular}

Median TSH (2.12 IOR 1.12-3.60) alone was within the normal range in all types of AUB. But outliers and whiskers of box plot showed considerable cases of menorrhagia, metrorrhagia and polymenorrhoea having TSH above normal range, denoting hypo-functioning of thyroid gland. Box plot also showed cases below normal range in hypomenorrhoea (Figure 2).

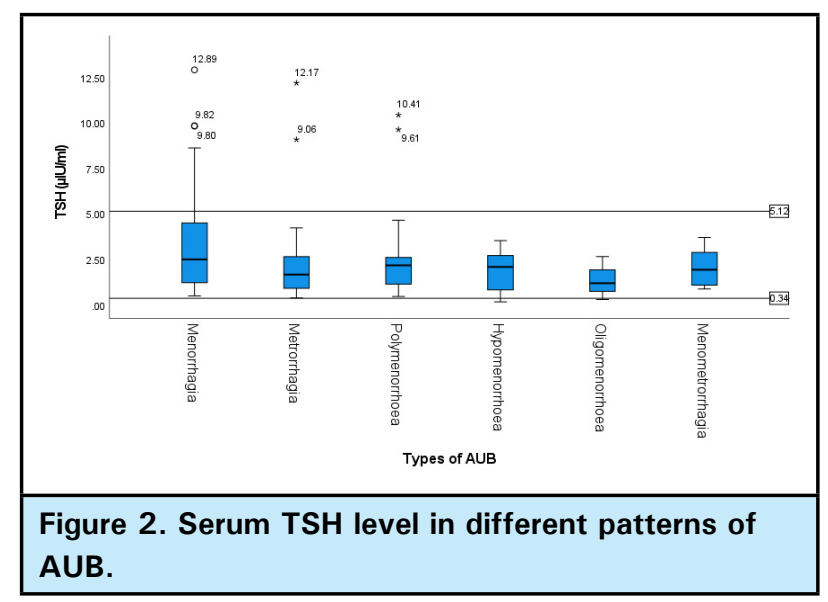

\section{DISCUSSION}

Abnormal uterine bleeding is one of the common finding among females of reproductive age. Among the wide spectrum of causes, from structural causes like polyps, leiomyoma etc. to non-structural causes, thyroid dysfunction is found as occult cause which may be readily missed out. Thyroid dysfunction, since being common in women ${ }^{8}$ and has been known to affect all events right from menarche to menopause, cannot be overlooked while treating any forms of menstrual disturbances. ${ }^{9}$

Our study consisted mainly of women from age group 25$34(37.9 \%)$ and age group 35-44 (32.6\%). In this study, $15.79 \%$ of total cases of AUB had thyroid dysfunction. Rest $84.21 \%$ of total cases of AUB were euthyroid. Out of cases with thyroid dysfunction, hypothyroid was most common followed by subclinical hypothyroid and hyperthyroid. Hypothyroidism is generally known to cause heavy and irregular menstrual bleeding and hyperthyroidism is generally associated with hypo, oligo and amenorrhoea. ${ }^{1}$ Our finding is similar to studies done in Nepal and India where researchers also found majority of AUB cases associated with euthyroidism followed by hypothyroidism, Subedi, et al. ${ }^{10}$ found $89.3 \%$ cases were euthyroid and $9.3 \%$ hypothyroid; Thakur, et al. ${ }^{11}$ found $84.9 \%$ as euthyroid and $13.9 \%$ hypothyroid; Kattel, et al. ${ }^{4}$ found $80 \%$ cases euthyroid and $11.1 \%$ as subclinical hypothyroid; Bhavani, et al. ${ }^{12}$ found $81 \%$ cases as euthyroid and $10 \%$ as subclinical hypothyroid; Gowri $\mathrm{M}$, et al. ${ }^{13}$ found $77.6 \%$ cases as euthyroid and $17.6 \%$ cases as hypothyroid. In contrast according to Ajmani, et al. ${ }^{14} 44 \%$ of the patients with menstrual disorder had thyroid disorders.

The most common pattern of AUB was found to be menorrhagia was most common 45 (47.37\%) followed by metrorrhagia 20 (21.05\%), polymenorrhoea 13 (13.68\%), menometrorrhagia 8 (8.42\%), hypomenorrhoea $6(6.31 \%)$, and oligomenorrhoea 3 $(3.15 \%)$. This is similar to study done by Kattel, et al. ${ }^{4}$ where menorrhagia (36.7\%) was most common complaint among AUB. Bhavani, et al. ${ }^{12}$ found the incidence of menorrhagia to be $54 \%$. Recent similar study in Nepal by Thakur, et al. ${ }^{11}$ also showed menorrhagia to be present among $40.5 \%$ cases of AUB. Second most common finding was metrorrhagia in our case which is similar to study done by Muzaffer, et al. $(35.4 \%) .{ }^{15}$ This is in contrast to study by Thakur, et al. ${ }^{11}$ in which polymenorrhoea was second most common finding.

Observing individual types of AUB, menorrhagia was mostly associated with overt hypothyroidism (15.5\%) followed by subclinical hypothyroidism (4.5\%). Menorrhagia has been reported to occur in $32-56 \%$ of cases of myxedema. ${ }^{16}$ Polymenorrhoea was associated with subclinical hypothyroidism only (15.4\%). Oligomenorrhoea and hypomenorrhoea were associated with hyperthyroidism. This finding is similar to study done by Kattel, et al. ${ }^{4}$ Subedi, et al. ${ }^{11}$ and Byna, et al. ${ }^{17}$ 
TSH can be used as a screening test for every patient visiting gynaecology department with complaint of menstrual disorder. This will provide less financial burden to the patients rather than opting for whole thyroid function test. Median TSH in our study was found to be 2.12IU/L (1.12-3.60) which is in accordance with study done by Khatiwada, et al. ${ }^{18}$ in eastern Nepal who found median TSH to be 2 IU/L (1.0-4.0). Brayshaw, et al. ${ }^{19}$ also reported majority of premenstrual syndrome (35 out of 54 cases) on basis of abnormal TSH test.

This study is a cross sectional study so the cause-andeffect relation of thyroid dysfunction and AUB cannot be elaborated and thus this result cannot be generalized to all patients in our country. Random sampling with more representative sample followed by rigorous study design adjusting the confounding factor would be required in future to further put light on the topic.

\section{CONCLUSIONS}

Our study found substantial patients with AUB suffering from thyroid dysfunction which was similar to previous studies done in similar setting. Hypothyroidism was most common finding in menorrhagia and metrorrhagia and hyperthyroidism was found in oligomenorrhoea and hypomenorrhoea.

\section{ACKNOWLEDGEMENTS}

We thank all the patients for their cooperation and participation. We would like to thank Department of Gynaecology, Nobel Medical College Teaching Hospital for their constant support during patient acquisition and data collection.

\section{Conflict of Interest: None.}

\section{REFERENCES}

1. Dittrich R, Beckmann MW, Oppelt PG, Hoffmann I, Lotz L, Kuwert T, et al. Thyroid hormone receptors and reproduction. J Reprod Immunol. 2011 Jun;90(1):58-66. [PubMed | Full Text | DOI]

2. Rifai N, Horvath AR, Wittwer CT, editors. Tietz textbook of clinical chemistry and molecular diagnostics. 6th ed. St. Louis: Elsevier; 2018. p. 627. [Full Text]

3. Padubidri V, Daftary S. Howkin's \& Bourne shaw's textbook of gynecology. 16th ed. India: Elsevier; 2016. p. 335-9. [Full Text]

4. Kattel P. Thyroid function test in abnormal uterine bleeding. Nepal Journal of Obstetrics and Gynaecology. 2017;12(2):74-8. [Full Text | DOI]

5. Ramalho I, Leite H, Aguas F. Abnormal uterine bleeding in adolescents: a multidisciplinary approach. Acta Med Port. 2021 Mar 31;34(4):291-7. [PubMed | Full Text | DOI]

6. Kouides PA. Menorrhagia from a haematologist's point of view. Part I: initial evaluation. Haemophilia. 2002 May;8(3):330-8. [PubMed | Full Text | DOI]

7. Michiels JJ, Schroyens W, Berneman Z, van der Planken M. Acquired von Willebrand syndrome type 1 in hypothyroidism: reversal after treatment with thyroxine. Clin Appl Thromb Hemost. 2001 Apr;7(2):113-5. [PubMed | Full Text | DOI]

8. Kazerouni F, Amirrasouli H. Performance characteristics of three automated immunoassays for thyroid hormones. Caspian J Intern Med. 2012 Spring;3(2):400-4. [PubMed | Full Text]

9. Aryal M, Gyawali P, Rajbhandari N, Aryal P, Pandeya DR. A prevalence of thyroid dysfunction in Kathmandu University Hospital, Nepal. Biomedical Research. 2010;21(4):411-5. [Full $\underline{\text { Text] }}$
10. Redmond GP. Thyroid dysfunction and women's reproductive health. Thyroid. 2004;14 Suppl 1:S5-15. [PubMed | Full Text | DOI]

11. Subedi S, Banerjee B, Manisha C. Thyroid disorders in women with dysfunctional uterine bleeding. J Pathol Nepal. 2016 Sep;6(12):1018-20. [Full Text | DOI]

12. Bhavani N, Avanthi S, Aradhana G, Sangeeta C, Prasannakumar VS. A study of correlation between abnormal uterine bleeding and thyroid dysfunction. International Journal of Recent Trends in Science and Technology. 2015;14(1):131-5. [Full Text]

13. Thakur M, Maharjan M, Tuladhar H, Dwa $Y$, Bhandari S, Maskey S, et al. Thyroid dysfunction in patients with abnormal uterine bleeding in a tertiary care hospital: a descriptive cross-sectional study. JNMA: Journal of the Nepal Medical Association. 2020 May;58(225):333. [PubMed | Full Text | DOI]

14. Muzaffar M, Akhtar KA, Yasmin S, Rehman M, Iqbal W, Khan MA. Menstrual irregularities with excessive blood loss: a clinico-pathological correlation. J Pak Med Assoc. 2005 Nov;55(11):486. [PubMed | Full Text]

15. Gowri M, Radhika BH, Harshini V, Ramaiaha R. Role of thyroid function tests in women with abnormal uterine bleeding. Int J Reprod Contracept Obstet Gynecol. 2014 Jan;3(1):54-7. [Full Text]

16. Ajmani NS, Sarbhai V, Yadav N, Paul M, Ahmad A, Ajmani AK. Role of thyroid dysfunction in patients with menstrual disorders in tertiary care center of walled city of Delhi. J Obstet Gynaecol India. 2016 Apr;66(2):115-9. [PubMed | Full Text | DOI]

17. Scott Jr JC, Mussey E. Menstrual patterns in myxedema. Am J Obstet Gynecol. 1964 Sep;90(2):161-5. [ $\underline{\text { PubMed I Full Text }}$ | DOI] 
18. Byna P, Siddula S, Kolli S, Shaik MV. Histopathological correlation of abnormal uterine bleeding in perimenopausal women. Int J Reprod Contracept Obstet Gynecl. 2015;4(6):1875-8. [Full Text | DOI]

19. Khatiwada S, Gautam S, Rajendra KC, Singh S, Shrestha S, Jha $\mathrm{P}$, et al. Pattern of thyroid dysfunction in women with menstrual disorders. ACCLM. 2016 May;2(1):3-6. [ Full Text [ DOI]

20. Brayshaw ND, Brayshaw DD. Thyroid hypofunction in premenstrual syndrome. N Engl J Med. 1986 Dec;315(23):1486-7. [PubMed | Full Text | DOI]

This work is licensed under a Creative Commons Attribution 4.0 International License. The images or other third party material in this article are included in the article's Creative Commons license, unless indicated otherwise in the credit line; if the material is not included under the Creative Commons license, users will need to obtain permission from the license holder to reproduce the material. To view a copy of this license, visit http://creativecommons.org/licenses/by/4.0/ 